\title{
Florida-Friendly Plants for Stormwater Pond Shorelines ${ }^{1}$
}

\author{
Gail Hansen and Shangchun $\mathrm{Hu}^{2}$
}

Selecting aquatic and shoreline plants for stormwater ponds is more challenging than selecting plants for a typical landscape. Site conditions can vary greatly and are more difficult to control. For example, water depth sometimes fluctuates widely, creating wet and dry conditions. Water quality varies with rainfall and fertilizer inputs. Steep slopes can make plant establishment and retention difficult. The concept of using the right plant in the right place is particularly important in the shoreline environment because the planting area includes a dry slope and a littoral shelf with shallow and deep water areas. Three questions to ask when selecting plants include 1) What environmental conditions does the plant need to grow? 2) How do you want the plant to function? 3) What do you want the plant to look like? Table 1 lists recommended plants that were selected based on these three questions.

\section{Growing Conditions}

A site inventory and analysis guides plant choices by noting environmental conditions in the pond and on the shoreline. Conditions that affect plants in aquatic habitats include water depth, fluctuating water levels, foraging fish, soil structure, the slope of the littoral shelf, and light availability. Conditions that affect upland plants include soil structure and bank slope. Selecting native aquatic or wetland species that are adapted to the environmental conditions could increase survival during establishment and sustainability following planting.

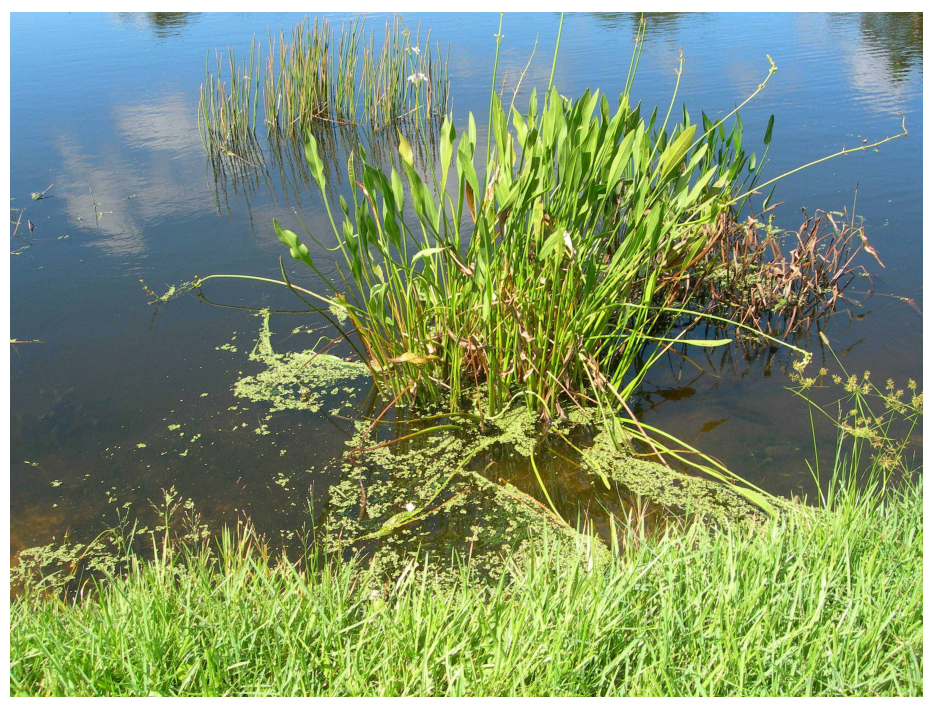

\section{Water Depth}

Water depth must be considered when choosing plants because wetland plants grow in three different zones (upper, middle, and lower littoral zones) with varying water depths. The littoral zones are those areas where the land and water meet along the shoreline, and they are described by the water depth. Emergent wetland plants are rooted in the soil in the shallow water of the upper littoral zone with the upper portion of the plant out of the water. Emergent wetland plants are further divided into short-stemmed marginal plants that do well in wet mud or sand and marginal plants that grow on the bank and prefer changing

1. This document is ENH1215, one of a series of the Environmental Horticulture Department, Florida Cooperative Extension Service, Institute of Food and Agricultural Sciences, University of Florida. Original publication date May 2013. Visit the EDIS website at http://edis.ifas.ufl.edu.

2. Gail Hansen, assistant professor, and Shangchun Hu, PhD student, Environmental Horticulture Department, Florida Cooperative Extension Service, Institute of Food and Agricultural Sciences, University of Florida, Gainesville, FL 32611. 
water levels. Floating wetland plants have roots that dangle and are rooted in the pond bottom in the middle littoral zone. Submerged plants grow entirely underwater and are typically located in the lower littoral zone where the water is deepest. Creating deeper areas by excavation can help expand the size of planted areas for submerged plants.

\section{Fluctuating Water Levels}

Ponds that have fluctuating water levels present a challenge when selecting plants. The plants need to thrive in both wet and dry conditions, sometimes for extended periods. Emergent plants that are more tolerant of drawdowns (exposed pond soil) include pickerelweed (Pontederia spp.), duck potato (Sagittaria lancifolia), golden canna (Canna flaccida), spikerush (Eleocharis spp.), and blue flag iris (Iris virginica).

\section{Foraging Fish: Controlling Grass Carp}

Although grass carp (sterile triploid) are sometimes used for biological control of aquatic vegetation, they can present problems with new plantings. Grass carp prefer submerged plants, but they also browse on the tips of young, tender, emergent plants. To prevent loss of new plants, install a barricade around the plants, such as four-wire fencing or plastic net fencing from the pond bottom to the top of the water until the plants are larger and less tender.

\section{Soil Structure}

Soil (substrate) conditions are important for plant growth. Rocky bottoms in the pond are too hard for plant roots to penetrate, and muck soil is too soft and unstable to anchor plants. Sandy soil with some organic matter (between rocks and muck) is usually best. Too much organic matter can create high levels of acids, methane, ethylene, and alcohols, which are toxic to plants.

\section{Slope of Littoral Shelf}

Steep slopes, which create excessive changes in water levels and growing conditions, make establishment more difficult. It is important to determine the average water level along the shoreline on a yearly basis because many plants will die if they are too wet or too dry for long periods. Manipulating the depth and slope by grading is one of the best ways to encourage plant growth. Littoral zone width often increases as the pond gets older because water movement over time increases sedimentation from bank erosion, which decreases the depth of the pond.

\section{Slope of Pond Bank}

The slope of the bank leading to the water's edge can present challenges for the establishment of a no-mow or no-maintenance plant buffer zone. The plant buffer functions as a protective barrier by preventing fertilizer runoff and grass clippings from entering the pond. To establish plant material, several techniques can be used to prevent erosion and capture irrigation water for the slope plants. Mini-baffles (landscape timbers or bio-logs) installed on the downhill side of plants hold water and keep soil from eroding. Porous landscape fabric such as burlap or jute also traps sediment and water. Rip-rap made from stone, concrete rubble, or pavers can help slow water runoff at outfalls, and swales and berms along the bank intercept and slow water movement, allowing it to percolate.

\section{Light Availability}

Light availability is the most important factor in plant growth and is primarily determined by water clarity and depth. Water clarity is determined by organic color and suspended particles, both organic and inorganic. Bottomfeeding fish such as carp and catfish can increase suspended sediment, which blocks light and may limit plant growth. Slowing surface runoff with plant buffers and no-mow zones and using rip-rap at drain discharge areas can help decrease turbidity (cloudy water caused by suspended soil particles) from water movement. Nutrient levels from both soil and humans in ponds can affect light availability by increasing algal growth, which decreases water clarity. Large trees on the shoreline with wide canopies that arch over the water can create a problem with shade. Plant large trees on the north side of the pond so the shadow is cast primarily on the pond bank, particularly in the winter.

\section{Function}

When selecting plants, it is important to consider plant function for that particular site. Functional characteristics include foliage density to block views, root mass density and depth to prevent erosion, stalk density to buffer water movement, and the ability to take up nutrients and pollutants to improve water quality.

\section{Erosion Control}

Trees in the water at the pond edge can help control erosion by breaking up the wind and wave action that contributes to it. Large trees that do well in wet conditions include red maple (Acer rubrum), loblolly bay (Gordonia lasianthus), and bald cypress (Taxodium spp.). Strongly rooted emergent plants also help prevent erosion by buffering the wave action that undermines upland plant roots. Emergent 
plants include spikerush (Eleocharis spp.), pickerelweed (Pontederia cordata), and duck potato (Sagittaria lancifolia).

\section{Visual Quality}

Most people enjoy a variety of color, texture, and forms to create a pleasing composition that enhances the aquatic habitat. In aquatic environments, people generally prefer plants that grow in clumps with large, coarse-textured green foliage and colorful flowers. Aesthetically, they also prefer plants that don't block the water view, are neatly organized in the landscape through repetition, and have a less weedy or messy look. The recommended plants in Table 1 were selected for their performance on pond shorelines and the visual characteristics typically preferred by homeowners. Some plants, such as soft rush (Juncus effuses) and American bulrush (Scirpus americanus), do well on shorelines but were not included in the table because they tend to have a more "weedy" look. California bulrush (Scirpus californicus) was also not included because the height can block views of open water. Submerged plants, such as eel grass (Vallisneria americana), were also not included because they are not visible, so aesthetic appeal is not a consideration.

\section{Color}

Color is usually the most attractive visual characteristic of plants, but it also is the most fleeting, as most plants only display prominent color during short bloom periods. The site's light qualities-sunny or shady areas-affect the perception of color. Warm colors, such as white, yellow, orange, and red, show up more in aquatic and shady environments because they contrast with the darker blues, greens, and browns of water and foliage. Cool colors, such as blues and dark purples, are less noticeable because they tend to blend with greens. Including a variety of greens in the aquatic plants creates interest year-round.

\section{Texture}

Textures are typically described as coarse (large, broad leaves and big stems) medium (average leaves and stems), or fine (tiny leaves, thin stems). Texture can provide contrast and interest, particularly when color variety is lacking. Stormwater ponds are often viewed from a distance, so bold-textured plants with large, broad leaves and big flowers show better. Use a fine-textured plant, such as a grass, to contrast with the bold texture and provide more interest.

\section{Form}

Growth habit or form is the most recognizable plant quality. Choose the plant form most appropriate for the desired function. It is important to remember that plants, especially larger plants and trees, change over time as they grow. Make your choice based on the full-grown size of the plant, but also consider the form at planting and intermediate stages of growth. Form also helps determine if plant material should be used in masses or as individual specimens. In large, open areas such as ponds, large, upright plants with well-defined leaves that grow in large clumps are often preferred. Floating plants with broad, flat leaves, such as water lilies, work well as long as they don't spread and cover the entire pond surface. A lake mower can be used to control lilies by selectively cutting some lily pads and leaving others for fish habitat. Because lilies spread their roots (rhizomes) laterally, the only other method to prevent spread is planting in submerged containers.

\section{Size}

It is important to consider the size of the plant when it is fully mature. Tall plants can sometimes block views when they are mature, so consider height as well as spread. The slope to the water affects the visual height of the plant, depending on the plant's location on the slope. Tall plants at the top of the slope can block the view of the water, so locate low-growing plants at the top of slope and taller plants at the bottom. Remember to consider the amount of flooding (or occasional standing water) they can tolerate if they are lower on the slope.

\section{Recommended Plants}

Although Florida-Friendly Landscaping ${ }^{\text {Tax }}$ plants include native and non-native plants, the plants recommended for the water edge zone are natives, as required by Florida regulations for planting in water bodies. Native plants are not required on the bank slope zone, but the recommended plants typically do well on dry slopes. Generally, the plants in Table 1 were selected for their foliage size, variety of textures, flower color, growth habit and height, aesthetic acceptability, survivability in varying water depths, ability to withstand wet and dry conditions, and ability to grow in a wide range of zones.

\section{Additional Resources}

Denny, G., and G. Hansen, G. 2013. Right Plant, Right Place: The Art and Science of Landscape Design-Plant Selection and Siting. ENH1156. Gainesville: University of Florida 
Table 1. Recommended plants for stormwater pond shorelines

\begin{tabular}{|c|c|c|c|c|}
\hline \multicolumn{5}{|c|}{ Water edge zone } \\
\hline Plant & Height & Light & Water depth & USDA zone \\
\hline $\begin{array}{l}\text { Arrowhead } \\
\text { Sagittaria latifolia }\end{array}$ & $3.5^{\prime}$ & Full sun to partial shade & $6^{\prime \prime}-12^{\prime \prime}$ & $5-10$ \\
\hline $\begin{array}{l}\text { Blue flag iris } \\
\text { Iris virginica }\end{array}$ & $2^{\prime}$ & Partial shade & $\begin{array}{l}\text { Moist to wet; water } \\
\text { edge }\end{array}$ & $8 b-11$ \\
\hline $\begin{array}{l}\text { Duck potato } \\
\text { Sagittaria lancifolia }\end{array}$ & $3^{\prime}$ & Full sun to partial shade & 6"-12" & $6-10$ \\
\hline $\begin{array}{l}\text { Fragrant water lily } \\
\text { Nymphaea odorata }\end{array}$ & Floating & Full sun to partial shade & $30^{\prime \prime}-36^{\prime \prime}$ & $8 a-11 b$ \\
\hline $\begin{array}{l}\text { Golden canna } \\
\text { Canna flaccida }\end{array}$ & $3^{\prime}$ & Full sun to partial shade & $12^{\prime \prime}-18^{\prime \prime}$ & $8-10$ \\
\hline $\begin{array}{l}\text { Pickerelweed } \\
\text { Pontederia cordata }\end{array}$ & $3^{\prime}$ & Full sun to partial shade & $6^{\prime \prime}-18^{\prime \prime}$ & $3 b-10$ \\
\hline $\begin{array}{l}\text { Sand cord grass } \\
\text { Spartina bakerii }\end{array}$ & $4^{\prime}$ & Full sun & Dry to wet; water edge & $8 b-11$ \\
\hline $\begin{array}{l}\text { Spikerush } \\
\text { Eleocharis cellulosa \& interstincta }\end{array}$ & $2.5^{\prime}$ & Full sun to partial shade & $6^{\prime \prime}-12^{\prime \prime}$ & $8 a-11 b$ \\
\hline $\begin{array}{l}\text { Swamp lily } \\
\text { Crinum americanum }\end{array}$ & $2^{\prime}$ & Partial shade & $3^{\prime \prime}$ & $7-11$ \\
\hline \multicolumn{5}{|c|}{ Bank slope zone } \\
\hline $\begin{array}{l}\text { African iris } \\
\text { Dietes iridioides }\end{array}$ & $3^{\prime}$ & Full sun to partial shade & Dry to wet & $8 b-11$ \\
\hline $\begin{array}{l}\text { Blue mistflower } \\
\text { Conoclinium coelestinum }\end{array}$ & $2^{\prime}$ & Full sun to partial shade & Moist & $4-11$ \\
\hline $\begin{array}{l}\text { Blue porterweed } \\
\text { Stachytarpheta jamaicensis }\end{array}$ & $2^{\prime}$ & Full sun & Dry to moist & $9-11$ \\
\hline $\begin{array}{l}\text { Fakahatchee grass } \\
\text { Tripsacum dactyloides }\end{array}$ & $4^{\prime}$ & Full sun to partial shade & Dry to moist & $8-11$ \\
\hline $\begin{array}{l}\text { Florida gamagrass } \\
\text { Tripsacum floridanum }\end{array}$ & $3^{\prime}$ & Full sun to partial shade & Dry to wet & $8-11$ \\
\hline $\begin{array}{l}\text { Muhly grass } \\
\text { Muhlenbergia capillaris }\end{array}$ & $3^{\prime}$ & Full sun & Dry to wet & $7-11$ \\
\hline $\begin{array}{l}\text { Passion vine } \\
\text { Passiflora incarnata }\end{array}$ & $0.5^{\prime}$ & Full sun & Moist & $8-11$ \\
\hline $\begin{array}{l}\text { Scorpion tail } \\
\text { Heliotropium angiospermum }\end{array}$ & $1.5^{\prime}$ & Full sun to partial shade & Dry & $10-11$ \\
\hline
\end{tabular}

Institute of Food and Agricultural Sciences. http://edis.ifas. ufl.edu/ep416.

Florida LAKEWATCH. 2007. A Beginner's Guide to Water Management: Aquatic Plants in Florida Lakes. Information Circular 111. Gainesville: University of Florida Institute of Food and Agricultural Sciences.

White, G. F., E. B. Worthington, and V. C. Ackerman. 1973. Man-Made Lakes: Their Problems and Environmental Effects. Richmond, VA: William Byrd Press. 